UDC 53.087.4+53.072.4

DOI: $10.30748 /$ soi.2020.162.02

L. Batyuk ${ }^{1}$, N. Kizilova ${ }^{2}$

${ }^{1}$ Kharkiv National Medical University, Kharkiv

${ }^{2}$ V.N. Karazin Kharkiv National University, Kharkiv

\title{
MONITORING SYSTEM OF BIOPHYSICAL PROPERTIES OF THE RED BLOOD CELLS OF PATIENTS FOR MEDICAL DIAGNOSIS PURPOSES
}

\begin{abstract}
Modern medical diagnostics is impossible without high-tech means of collecting information about the patient's condition, in particular, the biochemical properties of blood and other tissues, physiological signals in the format of time series, and medical images as well. Extensive use of automatic methods of information processing and decision-making based on mathematical models, expert systems, and artificial intelligence is an integral part of the tomorrow's medicine. Such approaches significantly increase the accuracy of diagnosis and the effectiveness of the prescribed treatment, but this requires the availability of properly structured databases with the results of both successful / unsuccessful treatments, and a complete set of necessary analyses and tests for each patient. This paper discusses the most important components of such database and public health monitoring system. The main issues are the standardization of data format, approaches, methods and laboratory equipment used to unify monitoring, diagnosis and control over the treatment. The importance of using additional physical parameters of blood cells and tissues to increase the efficiency of medical diagnostics with artificial intelligence is shown. The sedimentation curves corresponding to stable normal, stable increased and unstable erythrocyte aggregation rate are given. It is shown that the time to reach the maximum cell sedimentation rate can be calculated on a 2-phase model of blood suspension, indicators of which could be accumulated in the database, which will allow the extraction of additional diagnostic information using novel statistical and mathematical methods. Typical dependences of erythrocyte dielectric constant curves on temperature for oncology patients are given. It is shown that storage in the database the values of dielectric permittivity of red blood cells measured at different temperature and frequencies of electromagnetic fields applied in the dielectrometer, provides significant material for a more detailed study of the patterns of development of various diseases and finding the most sensitive indices for their timely detection.
\end{abstract}

Keywords: monitoring systems, databases, decision making, biophysics, red blood cells, mathematical modeling, medical diagnostics.

\section{Introduction}

Modern information technologies, statistical methods of information processing and mathematical modeling allow processing large amounts of various medical and biological information for decision making on the disease severity in a particular patient. It is of great importance for determination the necessary treatment, assessing its quality and developing the rehabilitation and prevention tools after the treatment. [1-3]. The indispensable information consists of verbal descriptions of personal data (age, sex, anamnesis, patient complaints, symptoms), numerical data of standard test results (histological, clinical and biophysical tests of blood, urine, etc.), time series (electrocardiogram, encephalogram, rheovasogram, etc.), medical images (X-ray and ultrasound ultrasound images, CT scans, etc.), 3D images (synthesized replicas of internal organs, bones, dentition, vascular systems, etc.) and 4D data (deployed over time 3D images, for example, magnetic resonance MRI data on blood flow through various vessels, muscle contractions, movement of heart valves, eyes, etc.) [4].

For better quality and more accurate diagnosis and control of treatment, the data should be gradually accumulated during the life span of the individual with the possibility of access to the entire database (DB) of the patients and the use of information processing systems, mathematical modeling and artificial intelligence (AI) to make decisions and organize the process of treatment and rehabilitation of the patient [5].

The system of accumulation and processing of information and decision-making is of great importance in the case of infectious diseases, as indicated, in particular, by the dynamics of the spread of viral pandemics, such as COVID19. Studies of the cardiovascular diseases, metabolic disorders, occupational and environmental diseases, which are common throughout the world, but have their own geographical, climatic, sociocultural and others specific factors [1].

Cancer may not have any manifestations for almost the entire life of the patient, but it suddenly arises and develops rapidly [5]. For the diagnosis of oncology the clinical tests on tumor markers (OM) [6], genetic tests for the presence of relevant mutations [7], as well as changes in the biophysical properties of blood cells [8-9] are additionally used. Erythrocyte function is related to the supply of oxygen and nutrients to each cell in the internal organs and tissues, as well as the excretion of oxygen dioxide and metabolic products, including toxins and products of structural disintegration of 
tumor-infiltrated tissues. Therefore, erythrocytes are the earliest to experience noticeable changes in their mechanical, electrical, magnetic, optical and other physical properties, even at the early stages of tumor formation and development [5; 8-9].

The aim of this work is to analyze the physicochemical (biochemical and biophysical) properties of cells and tissues, laboratory tests, technical equipment, mathematical approaches and software required for medical diagnostics using the computer-assisted monitoring systems (MS) based on multidimensional DB.

\section{Statement of basic materials}

\section{Biochemical and biophysical properties of tissues for clinical diagnosis}

The properties of cells of different tissues can be examined after biopsy that is usually prescribed based on preliminary biochemical tests, ultrasound, CT, MRI, angiography and other examinations, while the properties of blood cells and plasma, urine and other easily accessible biological liquids can be examined from their microportions. The concentrations of OM specific to different types of tumors are important indicators of their potential development, but there are also other reasons of their rise (false-positive OM values). Diagnostic analysis requires regular data on OM concentrations in time to detect their sustained growth associated with the development of malignant tumors, not with physiological processes. Relative high cost of complex biochemical and genetic analyzes as well as regular CT, MRI, PET (positron emission computed tomography) examinations confines permanent storage of such data especially in the developing countries.

Regular testing and accumulation of information on $\mathrm{OM}$ concentrations in a given patient in the relevant databases is important for:

- Diagnosis of certain types of tumors, such as brain, when biopsy is not possible;

- Large-scale population cancer studies, because in some countries the specificity and sensitivity of some OMs are higher than in other countries, but detailed population data for each type of OM are not available, which requires accumulation more data and its additional study;

- Detection of recurrences of the disease after treatment and planning repetitive treatments, taking into account the dynamics of the tumor's response to previous treatment;

- Assessment the size and aggressiveness of the tumor, which correlate with the concentrations of OM, for appropriate individual treatment scheduling.

The above listed components are important for both population and personalized medicine. Such studies may be conducted in the near future using nanofluid immunoassay technologies, lab-on-a-chip and lab-on-adisk techniques, which cost gradually decreases [9].
Recent studies have shown, the biophysical properties associated with the tumor microenvironment are important modulators of cell behaviour and function [10-11]. In particular, the adhesion and mechanical stiffness of the cells are important during carcinogenesis, as they seriously affect the ability of the tumor to spread in the tissues and form metastases in new locations.

The rigidity of the extracellular matrix (EM) affects the ability of cells to separate and be transported with the blood flow [12-14]. Measuring the stiffness of EM or tissue is an important diagnostic component for cancer detection. The cancer-produced changes in the properties of EM persist for a long time and have less individual heterogeneity compared to protein or genetic markers, therefore, they are more reliable for diagnostics than OM. On the other hand, the study of proteins or transcripts associated with kinase gives an early concept on the potential transition of cells to metastasis. Colocalization of the factors of transcription such as YAP / TAZ [12], makes it possible to determine whether cells undergo metastatic changes. Thus, the biophysical properties of the tumor microenvironment are important markers for early diagnosis of cancer [4$5 ; 9 ; 15]$.

Biochemical analysis of blood samples remains the simplest way to test the concentrations of various substances, such as OM, products of tumor metabolism and structural disintegration of the tumor-infiltrated tissues. These changes also affect the mechanical and biophysical properties of red blood cells (RBC), such as their adhesion coefficient $\alpha$, aggregation capacity $\Phi$, electric charge $q$, electric conductivity $\sigma$, dielectric permittivity $\varepsilon$ and others. Due to complex measurement technologies, in laboratory these properties are estimated indirectly, by measuring the erythrocyte sedimentation rate (ESR), electrophoretic mobility (EPM), absorption of electromagnetic energy, etc. [15]. These tests do not require complex measurement techniques, but the processing of the measured values requires appropriate mathematical models that allow quantitative estimations of the physical properties $(\alpha, \Phi, q, \sigma, \varepsilon, \ldots)$ of the cells based on the measured EPM in the electrophoretic device or on the ESR in the diluted erythrocyte suspension. The mechanical properties of blood cells can be studied in microfluidic devices that are not used in everyday laboratory tests yet. The microfluidic techniques measure the modulus of elasticity (Jung) $E_{j}$ and viscosity (fluidity) $\mu_{j}$ of the cells, which are very important for the cancer diagnosis [10-12].

\section{Components of DB and MS}

Personal information on the patient is introduced into the DB by the doctor / laboratory assistant (Fig. 1). Then doctor prescribes the medical examination, which 
includes biochemical, physiological, histological and other laboratory tests (LT) in the form of time series, 2D and 3D images, or 4D spatio-temporal information, as well as the physical parameters measured on blood cells or tissue samples (ESR, EPM, etc.). The preliminary diagnosis is also introduced into the DB formed by information from other patients. The knowledge database (KDB) contains modern information on diseases and their symptoms. Then the encoded anonymous information is stored in the general DB and sent to the block of statistical analysis, processing and interpretation of results on the basis of the corresponding mathematical models and KDB. The time series and medical images are automatically studied to identify specific patterns proper to the preliminary diagnosed disease / impairment and the results are sent to the doctor and DB. Based on new data, doctor confirms, clarifies or changes the preliminary diagnosis and determines the therapy or surgery recommended. At the same time, the results of the analysis are sent to the patient's $\mathrm{DB}, \mathrm{KB}$ and for training of one of the available AI specified on the recognition of a specific disease/disorder. The diagnosis and recommendations of the AI and doctor are compared, stored and used for the treatment of the patient, further teaching of the AI and replenish personal DB and KDB (Fig. 1).

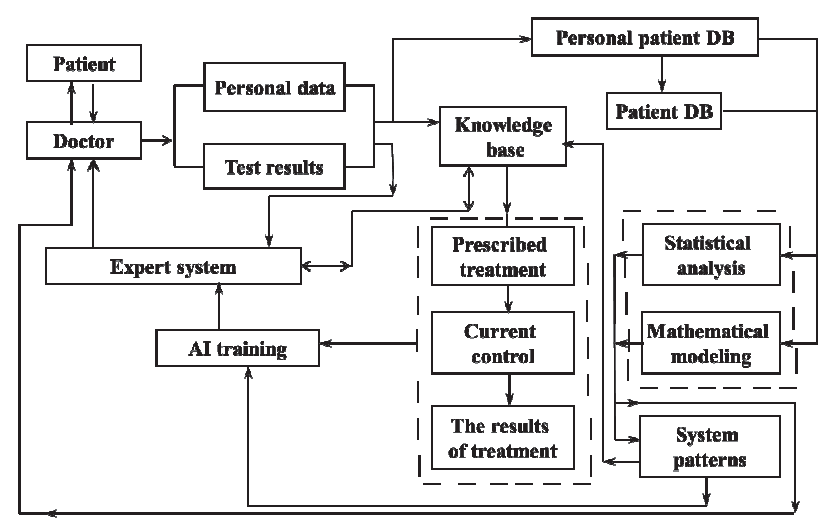

Fig. 1. Components of MS, processing and output of diagnostic information

If necessary, the foregoing steps are repeated in the form of iterations to improve the diagnosis, treatment, rehabilitation and further maintenance of the patient's health, which leads to replenishment of $\mathrm{DB}$ and $\mathrm{KDB}$, increase the accuracy, efficiency and sensitivity of AI, comparison of the effectiveness of different types of AI, as well as the expert system (ES) for decision making. The ES works independently of the doctor on the basis of $\mathrm{DB}, \mathrm{KDB}, \mathrm{AI}$ and current information from the patient. The use of such an approach (AI + expert-in-theloop) has already shown its advantages in diagnoses compared to a doctor or even to a group of experienced international experts. Large-scale randomized trials have shown higher accuracy of AI in fast diagnosing lung cancer, skin cancer, and a number of other diseases compared to the results of a slower work of a team of $>100$ best medical experts from different countries (see literature review in $[4-5 ; 10])$. AI also demonstrated its ability to develop reliable diagnostic criteria for cancer recognition based on the learning sequences of medical images. The physical parameters of the RBC, biological liquids and tissues could also be analysed by AI together with 2D, 3D and 3D medical data that increases the reliability and sensitivity of the ES, and decreases the costs of the medical examinations needed.

Now many of the physical parameters of cells and tissues are studied in research laboratories only, and the corresponding indexes could be proposed for medicine after thorough validation. The history of medicine knows many examples when quite complex mathematical indicators, such as heart rate variability (HRV), heart entropy or heart rate, fractal dimension and Lyapunov exponent of a physiological signal, its energy density at low and high frequencies, intensity of the propagated and reflected pulse waves, etc. [1-3] became and integral part of the routine diagnostic practice of specialized hospitals. Such parameters can be crucial in correct diagnostics and prescription of therapy or surgery for decision-making by ES.

\section{Physical characteristics of cells and tissues in medical diagnostics}

Physical properties of blood samples, blood cells and other tissues are widely used in medicine. Some of them are measured directly (blood cell concentrations, blood viscosity, plasma viscosity, etc.), while others can be indirectly estimated from the measured integral parameters, which depend on their physical characteristics. The latter needs the corresponding mathematical formulas, which are obtained empirically or from appropriate mathematical models. For instance the ESR value or sedimentation curves measured on the RBC, platelets and other cells settled in a tube can be used for quantitative estimation of their $\alpha, \Phi, q, \sigma$ and $\varepsilon$ values. Measured EPM or magnitophoretic mobility of the cells as integral parameters can be used then for estimations of their $q$ and magnetic moment.

Some of these tests are widely used in everyday clinical practice in many countries (such as ESR, EPM), others are specific for some countries or have different standards for the test conduction. For example, the ESR test is performed in the USA and Europe in different ways. The samples of arterial or venous blood, the vertical or inclined sedimentation tubes of $10-30 \mathrm{~cm}$ long and $1-3 \mathrm{~mm}$ in diameter, the test duration $1-3$ hours, in a gravity field or in centrifuges (tests Westergren, Wintrobe, Panchenkova, etc.) can be used. Despite some correlations in the results of ESR and other tests performed by different methods, for the purposes of development of a generalized DB and MS which allow data 
processing, elaboration and acceptance of appropriate standards for each medical test, for the physiological data in the form of time series and for medical images are necessary.

The most important physical properties that could be also essential for AI are listed in Tabl. 1. All indicators are scalar values; many of them depend not only on the physiological condition of the patient (sick or not), but also on the shape and size of cells or tissue sample, temperature (of the body or in the laboratory conditions). In addition, all indicators were calculated during the registration of certain dynamical processes: movement, rotation, orientation, and oscillation of the sample components, which are time-dependent. Even the simplest ESR test can be recorded as a sedimentation curve rather than a scalar 1-hour index.

Table 1 Values of physical quantities of blood parameters that can be used for medical diagnostics and learning of AI

\begin{tabular}{|c|c|c|c|}
\hline Description & $\begin{array}{l}\text { Designa- } \\
\text { tion }\end{array}$ & Units & $\begin{array}{c}\text { Typical } \\
\text { values }\end{array}$ \\
\hline Hematocrit & $H t$ & $\%$ & $36-48$ \\
\hline Erythrocyte concentration & $C_{e}$ & $1^{-1}$ & $(3.9-5.5) \cdot 10^{12}$ \\
\hline $\begin{array}{l}\text { Average erythrocyte vol- } \\
\text { ume }\end{array}$ & $V_{e}$ & $\mathrm{~mm}^{3}$ & $75-122$ \\
\hline Membrane thickness & $h_{m e}$ & $\mathrm{~nm}$ & $6.5-9.2$ \\
\hline $\begin{array}{l}\text { The modulus of elasticity } \\
\text { of the erythrocyte and its } \\
\text { membrane }\end{array}$ & $\begin{array}{l}E_{e} \\
E_{m e}\end{array}$ & $\mathrm{~Pa}$ & $\begin{array}{l}12-498.2 \\
15.7-623\end{array}$ \\
\hline $\begin{array}{l}\text { Poisson's ratio of erythro- } \\
\text { cyte and its membrane }\end{array}$ & $\begin{array}{l}v_{e} \\
v_{m e}\end{array}$ & - & $\begin{array}{l}0.45-0.5 \\
0.4-0.48\end{array}$ \\
\hline Blood density & $\rho_{b}$ & $\mathrm{~g} / \mathrm{cm}^{3}$ & $1.048-1.066$ \\
\hline Blood viscosity & $\mu_{b}$ & $\mathrm{cP}$ & $3-22.3$ \\
\hline Blood plasma viscosity & $\mu_{b p}$ & $\mathrm{cP}$ & $1.1-1.7$ \\
\hline $\begin{array}{l}\text { Electric charge of erythro- } \\
\text { cytes (zeta potential) }\end{array}$ & $\zeta$ & $\mathrm{mV}$ & $15-25$ \\
\hline $\begin{array}{l}\text { Magnetic moment of } \\
\text { erythrocytes }\end{array}$ & $\vec{M}$ & CGS & $(3.6-4.4) \cdot 10^{-8}$ \\
\hline $\begin{array}{l}\text { Electrical conductivity of } \\
\text { blood }\end{array}$ & $\begin{array}{l}k_{0} \\
k_{\infty}\end{array}$ & $\mathrm{S} / \mathrm{m}$ & $\begin{array}{l}0.5(\mathrm{LF}) \\
9 \cdot 10^{-3}(\mathrm{HF})\end{array}$ \\
\hline $\begin{array}{l}\text { Electrical conductivity of } \\
\text { blood plasma }\end{array}$ & $k_{0, b p}$ & $\mathrm{~S} / \mathrm{m}$ & $1.2\left(\mathrm{~T}=24^{\circ} \mathrm{C}\right)$ \\
\hline $\begin{array}{l}\text { Electrical conductivity of } \\
\text { erythrocyte membranes }\end{array}$ & $k_{0, \mathrm{~m}}$ & $\mathrm{~S} / \mathrm{m}$ & $5 \cdot 10^{-5}$ \\
\hline $\begin{array}{l}\text { Electrical conductivity of } \\
\text { the cytoplasm }\end{array}$ & $k_{0, \mathrm{cyt}}$ & $\mathrm{S} / \mathrm{m}$ & 0.5 \\
\hline $\begin{array}{l}\text { Dielectric permittivity of } \\
\text { erythrocytes at } T=36.6^{\circ} \mathrm{C} \text {, } \\
f=100 \mathrm{MHz}[18]\end{array}$ & $\varepsilon^{\prime}$ & - & $63.6-67.6$ \\
\hline $\begin{array}{l}\text { Dielectric permittivity of } \\
\text { erythrocytes at } T=36.6^{\circ} \mathrm{C} \text {, } \\
f=1000 \mathrm{MHz}[18]\end{array}$ & $\varepsilon^{\prime}$ & - & $52.4-60.9$ \\
\hline $\begin{array}{l}\text { Dielectric permittivity of } \\
\text { erythrocytes at } T=36.6^{\circ} \mathrm{C} \text {, } \\
f=2000 \mathrm{MHz}[18]\end{array}$ & $\varepsilon^{\prime}$ & - & $50.2-59.5$ \\
\hline
\end{tabular}

${ }^{*} \mathrm{LF}$ - low frequencies, $\mathrm{HF}$ - high frequencies

Fig. 2 shows the RBC sedimentation curves $h(t)$ of different types measured in the vertical tube in the centrifuge [16]. They have the same 1-hour index (measured at $t=60 \mathrm{~min}$, Panchenkov's method), but exhibit different dynamics at $t<60 \mathrm{~min}$, as well as different scalar indicators at $t=120 ; 180 \mathrm{~min}$ (Westergren and Wintrobe methods). Curves 1, 2, 3 correspond to a stable increased, stable normal and unstable erythrocyte aggregation rate accordingly. Thus, curve 1 quickly reaches a constant value and the ESR 1-hour index is reliable for clinical diagnostics. The stepwise curve 2 is unstable and, therefore, the 1-hour index is unreliable. Curve 3 demonstrates a slow initial sedimentation with its sudden acceleration after $t=60 \mathrm{~min}$, so that at $t=120$ min the scalar index may exceed the one in the curves 1 and 2. Thus, in this case, the 1-hour ESR is erroneous, and the sedimentation curve could be used as complex integral information for more precise diagnostics. Additional indexes like maximum sedimentation rate time(s) $t_{j}^{*}$ can be calculated from the curves based on a proper mathematical model of blood as a multiphase suspension (cells + plasma) [15]:

$$
t^{*}=\frac{1}{\Gamma H t}\left(\left(1+\frac{5 \Gamma}{13.5(1-H t)^{3.5}}\right)^{0.6}-1\right),
$$

where $\Gamma$ is the RBC aggregation rate, which is an important indicator of the suspension stability of the blood.

In that way, (1) allows calculating $\Gamma$ on the values of hematocrit $\mathrm{Ht}$ and $t_{j}^{*}$. If not only the standard 1-hour ESR index, but the curves $h(t)$ are accumulated in the $\mathrm{DB}$, additional valuable diagnostic information from the curves can be extracted with sophisticated statistical methods and mathematical models.

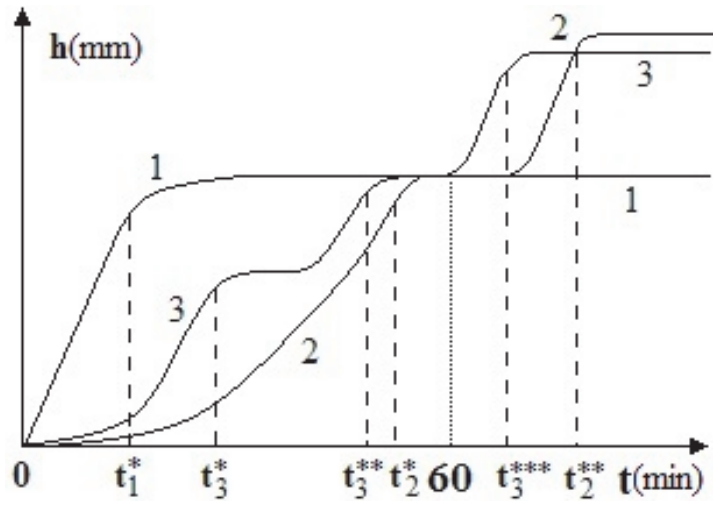

Fig. 2. Sedimentation curves $h(t): \sigma-(1), s-(2)$ and stepped (3) types; the values of $t_{j}^{*}$ correspond to the local maximum velocities (adapted from [16])

Analogously, the EPM measured on individual cells suspended in the saline or more complex solutions in a constant electric field $E$ of the capacitor can be considered as an integral diagnostic parameter. The measured velocity $U$ of the movement of the cells to the electrode can be calculated by the model of a charged spherical particle

$$
E P M \equiv \frac{U}{E}=\frac{\varepsilon \zeta}{4 \pi \mu_{f}},
$$


where $\varepsilon$ is the dielectric permittivity of matter between the electrodes, $\mu_{f}$ is the viscosity of the solution, $\zeta$ is the electric potential (zeta-potential) of the surface that separates the ions absorbed by the cell surface from the free ions of the solution. Formula (2) allows calculation of $\zeta$ as an important diagnostic value from the measured EPM data. In this case registration of the dynamical curves $\operatorname{EPM}(t)$ instead of a constant EPM value will allow obtaining more diagnostic information from the same set of measurements. In addition, conducting the electrophoretic mobility test in the external electric fields with different intensity and space distribution, will allow calculating the coefficients of inertia of the cells and visco-elasticity of their internal nuclei, viscous resistance forces for their translational, rotational and oscillatory motion. When the EPM test is conducted in the crossed electric and magnetic fields, the magnetic moment of the cells can be computed based on the corresponding mathematical model [15]. Therefore, valuable diagnostic information for the DB could be obtained at the expense of a small complication of standard medical tests.

Besides, the complex dielectric permittivity of cells $\varepsilon=\varepsilon^{\prime}+i \varepsilon^{\prime \prime}$, cell suspensions and tissues, where the real part $\varepsilon^{\prime}$ is the dielectric permittivity, and $\varepsilon^{\prime \prime}$ is the dielectric energy loss in the material, as in an imperfect dielectric, where $\varepsilon^{\prime}=\varepsilon^{\prime}(\omega, T), \varepsilon^{\prime \prime}=\varepsilon^{\prime \prime}(\omega, T)$, where $\omega$ is the frequency of the external electromagnetic field, $T$ is the temperature, can be used for AI teaching in ES. AI was even able to predict stroke based on the retina images of healthy individuals [17].

In the presence of tumors, myocardial infarction, stroke and a number of other diseases associated with significant changes in the composition of tissue fluid and blood plasma, noticeable variations in $\alpha, \Phi, q$, $\sigma$, and $\varepsilon$ values of RBC and plasma could be detected at the early stages of the disease development. Under such conditions, electrical and mechanical properties of $\mathrm{RBC}$ are most sensitive to biochemical changes caused by the disease. As a result, the typical dependences $\varepsilon^{\prime}(T)$ and $\varepsilon^{\prime \prime}(T)$ at $\omega=$ const differ in healthy volunteers and patients with cancer (Fig. 3) and some other diseases [4].

The dielectric parameters of cells change at each temperature $T \in\left[0 ; 54^{\circ} \mathrm{C}\right]$ due to gradual denaturation of the proteins composed the cells. Similar dependences were found for patients with hemorrhagic and ischemic stroke, in cancer patients before and after radiation exposure [4]. It is worth noting, Interestingly, after the corresponding anticancer therapy and with successful recovery the curves $\varepsilon^{\prime}(T), \varepsilon^{\prime \prime}(T)$ shift towards the normal values proper to healthy individuals.

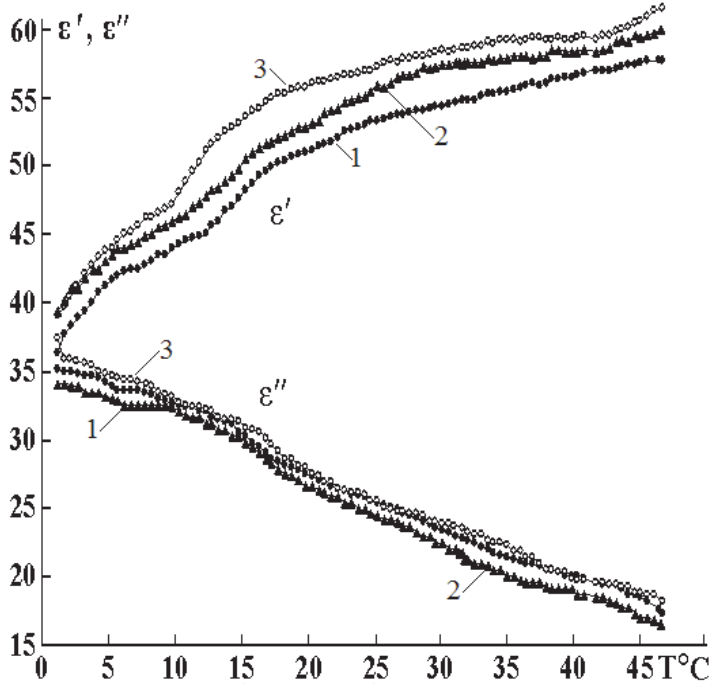

Fig. 3. Dependencies $\varepsilon^{\prime}(T)$ and $\varepsilon^{\prime \prime}(T)$ of erythrocytes in healthy donors (1), patients with breast cancer (2) and lung cancer (3) on a frequency of dielectric permittivity $9.2 \mathrm{GHz}$ (adapted from [18])

In that way, storage the curves $\varepsilon^{\prime}=\varepsilon^{\prime}(\omega, T)$, $\varepsilon^{\prime \prime}=\varepsilon^{\prime \prime}(\omega, T)$ were measured at different frequencies of the external electromagnetic field in a dielectrometer [4; $10 ; 18]$, provides significant material for more detailed diagnostics of diseases and elaboration of the most sensitive indexes for their early detection. The extended BD with medical information in the form of temporary, temperature, and other dynamical curves increases the amount of useful information for disease diagnosis and control of the treatment quality.

\section{Conclusions}

Thus, the extended DB and MS accounted for not only standard clinical information, tests and indexes but also various biophysical parameters of $\mathrm{RBC}$, blood and other biological liquids, especially their mechanical and electromagnetic properties can be efficiently used for permanent automatic monitoring of human health based on the results of statistical analysis of medical information from the patient's personal DB, numerical estimates based on appropriate mathematical models and KDB, as well as the use of AI. In addition, the accumulation of a general DB within the community, region, state, or country provides an opportunity to better understand the peculiarities of the development and treatment of diseases in close connection with geographical, climatic, ecological and other pecularities of the region / country.

It is especially important to develop common standards for all medical tests / examinations to be stored in the DB for both current and future usage. The main issues are the standardization of data format, approaches, methods and laboratory equipment used to unify monitoring, diagnosis, therapy/surgery prescription and control over the treatment and rehabilitation. Only under 
such conditions the statistical data analysis and AI will produce reliable decisions within the total MS. The AI + expert-in-the-loop approach in the MS is the most prom- ising concept for future population and personalized medicine.

\section{References}

1. Abdelhak, M., Grostick, S. and Hanken, M.A. (2016), Health Information. E-Book: Management of a Strategic Resource, Elsevier, $800 \mathrm{p}$.

2. Andreieva, D.N., Vdovichenko, T.V., Kizilova, N.M. and Nikolaiev, A.S. (2020), "Perspektyvni matematychni metody dlja rannjoji diaghnostyky porushenj systemy krovoobighu ljudyny" [Promising mathematical methods for early diagnosis of human circulatory disorders], Bulletin of V. Karazin Kharkiv National University, Ser. "Mathematical Modelling. Information Technology. Automated Control Systems”, No. 45, pp. 4-9. https://doi.org/10.26565/2304-6201-2020-45-01.

3. Kizilova, N.N. and Pakki, D.M. (2020), "Statystychnyj analiz danykh monitorynghu koronarnogho krovotoku dlja ghemodynamichnoji ocinky stupenja stenozu koronarnykh arterij" [Statistical analysis of coronary blood flow monitoring data for hemodynamic assessment of the degree of coronary artery stenosis], Bulletin of $V$. Karazin Kharkiv National University, Ser. "Mathematical Modelling. Information Technology. Automated Control Systems", No. 45, pp. 50-55. https://doi.org/10.26565/2304-6201-2020-45-06.

4. Batyuk, L.V. and Kizilova, N.N. (2019), Novel monitoring system for quantitative estimation of efficient medical treatment of diseases based on dielectric properties of blood samples, Bulletin of V. Karazin Kharkiv National University, Series "Mathematical Modelling. Information Technology. Automated Control Systems", No. 43, pp.4-10. https://doi.org/10.26565/2304-6201-2019-43-01.

5. Kizilova, N. (2019), Multidisciplinary approaches in cancer diagnosis and treatment: towards patient-specific predictive oncology, AS Cancer Biology, Vol. 3, No. 8, pp. 1-2.

6. Yadav, Sh., Barton, M.J. and Nguyen, N.-T. (2019), Biophysical properties of cells for cancer diagnosis, Journal of Biomechanics, Vol. 86, pp. 1-7. https://doi.org/10.1016/j.jbiomech.2019.02.006.

7. Pollard, S., Kalloger, S. and Weymann, D. (2020), Genetic testing for hereditary cancer syndromes: patient recommendations for improved risk communication, Health Expectations, pp. 1-9. https://doi.org/10.1111/hex.13062.

8. Weijia, Z., Kazuharu, K., Naoto, T.U. and Lidong, Q. (2013), A Brief Review of the Biophysical Hallmarks of Metastatic Cancer Cells, Cancer Hallmark, Vol. 1, No. 2/3, pp. 59-66. https://doi.org/10.1166/ch.2013.1010.

9. Batyuk, L. and Kizilova, N. (2018), Dielectric properties of red blood cells for cancer diagnostics and treatment, $A S$ Cancer Biology, Vol. 2, No. 10, pp. 55-60.

10. Batyuk, L. and Kizilova, N. (2018), Modeling of dielectric permittivity of the erythrocytes membrane as a three-layer model, Development trends in medical science and practice: the experience of countries of Eastern Europe and prospects of Ukraine, Baltija Publishing, Riga, pp. 18-37. https://doi.org/10.30525/978-9934-571-31-2.

11. Tang, Z. and Ma, Z. (2017), Multiple functional strategies for amplifying sensitivity of amperometric immunoassay for tumor markers: A review, Biosensors and Bioelectronics, Vol. 98, pp. 100-112. https://doi.org/10.1016/j.bios.2017.06.041.

12. Gkretsi, V. and Stylianopoulos, T. (2018), Cell adhesion and matrix stiffness: coordinating cancer cell invasion and metastasis, Frontiers in Oncology, Vol. 8, 145. https://doi.org/10.3389/fonc.2018.00145.

13. Wullkopf, L., West, A.-K.V., and Leijnse, N. (2018), Cancer cells' ability to mechanically adjust to extracellular matrix stiffness correlates with their invasive potential, Molecular Biology of the Cell, Vol. 29, pp. $2378-2385$. https://doi.org/10.1091/mbc.E18-05-0319.

14. Zanconato, F., Cordenonsi, M. and Piccolo, S. (2019), YAP and TAZ: a signaling hub of the tumour microenvironment, Nature Reviews Cancer, Vol. 19, pp. 454-464. https://doi.org/10.1038/s41568-019-0168-y.

15. Kizilova, N. (2019), Electromagnetic Properties of Blood and Its Interaction with Electromagnetic Fields, Advances in Medicine and Biology, Vol. 137, NOVA Sci. Publ., pp. 1-74.

16. Baranets, V.A., Datsok, O.M. and Kizilova, N.N. (2019), "Matematycheskoe modelyrovanye osedanyja v suspenzyjakh aghreghyrujushhykh mykrochastyc vo vneshnem pole syl" [Mathematical modelng of sedimentation in the suspensions of aggregating microparticles in external fields], Mechanics. Collected volume, Gomel University Press, 12, pp. 5-15.

17. Schmidt-Erfurth, U., Sadeghipour, A. Gerendas, B.S., Waldstein, S.M. and Bogunović, H. (2018), Artificial intelligence in retina, Progress in Retinal and Eye Research, Vol. 67, pp. 1-29.

18. Batyuk, L.V., Gatash, S.V. and Gorobchenko, O.A. (2002), Dielectric properties of human erythrocytes in normal and carcinogenic state, Visnyk V.N. Karazin Kharkiv National University, Vol. 1, No. 10, pp. 54-57.

19. Bianco, B., Drago, G.P., Marchesi, M., Martini, C., Mela, G.S. and Ridella, S. (1979), Measurement of complex dielectric constant of human sera and erythrocytes, Transact. IEEE IM, Vol. 28, pp. 290-295.

\section{Список літератури}

1. Abdelhak M. Health Information E-Book: Management of a Strategic Resource / M. Abdelhak, S. Grostick, M.A. Hanken. - Elsevier, 2016. - 800 p.

2. Перспективні математичні методи для ранньої діагностики порушень системи кровообігу людини / Д.М. Андрєєва, Т.В. Вдовіченко, Н.М. Кізілова, А.С. Ніколаєв // Вісник Харк. нац. ун-ту. Сер. “Математичне моделювання. Інформаційні технології. Автоматизовані системи управління" . - 2020. - Вип. 45. - С. 4-9. https://doi.org/10.26565/23046201-2020-45-01 
3. Кізілова Н.М. Статистичний аналіз даних моніторингу коронарного кровотоку для гемодинамічної оцінки ступеня стенозу коронарних артерій / Н.М. Кізілова, Д.М. Паккі // Вісник Харк. нац. ун-ту. Сер. "Математичне моделювання. Інформаційні технології. Автоматизовані системи управління”. - 2020. - Вип. 46. - С. 50-55. https://doi.org/10.26565/2304-6201-2020-45-06.

4. Batyuk L.V. Novel monitoring system for quantitative estimation of efficient medical treatment of diseases based on dielectric properties of blood samples / L.V. Batyuk, N.N. Kizilova // Bulletin of V. Karazin Kharkiv National University, Series "Mathematical Modelling. Information Technology. Automated Control Systems". - 2019. - Issue 43. - P. 4-10. https://doi.org/10.26565/2304-6201-2019-43-01.

5. Kizilova N. Multidisciplinary approaches in cancer diagnosis and treatment: towards patient-specific predictive oncology / N. Kizilova // AS Cancer Biology. - 2019. - Vol. 3, No. 8. - P. 1-2.

6. Yadav Sh. Biophysical properties of cells for cancer diagnosis / Sh. Yadav, M.J. Barton, N.-T. Nguyen // Journal of Biomechanics. - 2019. - Vol. 86. - P. 1-7.

7. Pollard S. Genetic testing for hereditary cancer syndromes: patient recommendations for improved risk communication / S. Pollard, S. Kalloger, D. Weymann // Health Expectations. - 2020. -P. 1-9. https://doi.org/10.1111/hex.13062,

8. A Brief Review of the Biophysical Hallmarks of Metastatic Cancer Cells / Z. Weijia, K. Kazuharu, T.U. Naoto, Q. Lidong // Cancer Hallmark. - 2013. - Vol. 1, No. 2/3. - P. 59-66. https://doi.org/10.1166/ch.2013.1010.

9. Batyuk L. Dielectric properties of red blood cells for cancer diagnostics and treatment / L. Batyuk, N. Kizilova // AS Cancer Biology. - 2018. - Vol. 2, No. 10. - P. 55-60.

10. Batyuk L. Modeling of dielectric permittivity of the erythrocytes membrane as a three-layer model / L. Batyuk, N. Kizilova // Development trends in medical science and practice: the experience of countries of Eastern Europe and prospects of Ukraine. - Riga: Baltija Publishing, 2018. - P. 18-37. https://doi.org/10.30525/978-9934-571-31-2.

11. Tang Z. Multiple functional strategies for amplifying sensitivity of amperometric immunoassay for tumor markers: A review / Z. Tang, Z. Ma // Biosensors and Bioelectronics. - 2017. - Vol. 98. - P. 100-112. . https://doi.org/10.1016/j.bios.2017.06.041.

12. Gkretsi V. Cell adhesion and matrix stiffness: coordinating cancer cell invasion and metastasis. / V. Gkretsi, T. Stylianopoulos // Frontiers Oncology. - 2018. - Vol. 8. - 145. https://doi.org/10.3389/fonc.2018.00145.

13. Wullkopf L. Cancer cells' ability to mechanically adjust to extracellular matrix stiffness correlates with their invasive potential / L. Wullkopf, A.-K.V. West, N. Leijnse // Molecular Biology of the Cell. - 2018. - Vol. 29. - P. $2378-2385$. https://doi.org/10.1091/mbc.E18-05-0319.

14. Zanconato F. YAP and TAZ: a signalling hub of the tumour microenvironment / F. Zanconato, M. Cordenonsi, S. Piccolo // Nature Reviews Cancer. - 2019. - Vol. 19. - P. 454-464. https://doi.org/10.1038/s41568-019-0168-y.

15. Kizilova N. Electromagnetic Properties of Blood and Its Interaction with Electromagnetic Fields / N. Kizilova // Advances in Medicine and Biology. - NOVA Sci. Publ. - 2019. - Vol. 137. - P. 1-74.

16. Баранец В.А. Математическое моделирование оседания в суспензиях агрегирующих микрочастиц во внешнем поле сил / В.А. Баранец, О.М. Дацок, Н.Н. Кизилова // Механика. Сб. статей. - Гомель. - 2019. - Вып. 12. - С. 5-15.

17. Artificial intelligence in retina / U. Schmidt-Erfurth, A. Sadeghipour, B.S. Gerendas, S.M. Waldstein, H. Bogunović // Progress in Retinal and Eye Research. - 2018. - Vol. 67. - P. 1-29.

18. Batyuk L.V. Dielectric properties of human erythrocytes in normal and carcinogenic state / L.V. Batyuk, S.V. Gatash, O.A. Gorobchenko // Visnyk V.N. Karazin Kharkiv National University. - 2002. - Vol. 1, No. 10. - P. 54-57.

19. Measurement of complex dielectric constant of human sera and erythrocytes / B. Bianco, G.P. Drago, M. Marchesi, C. Martini, G.S. Mela, S. Ridella //Transact. IEEE IM. - 1979. - Vol. 28. - P. 290-295.

\section{Відомості про авторів:}

\section{Батюк Лілія Василівна}

кандидат біологічних наук

доцент кафедри Харківського національного

медичного університету,

Харків, Україна

https://orcid.org/0000-0003-1863-0265

\section{Кізілова Наталія Миколаївна}

доктор фізико-математичних наук

професор Харківського національного університету

ім. В.Н. Каразіна,

Харків, Україна

https://orcid.org/0000-0001-9981-7616

\section{Information about the authors:}

\author{
Liliya Batyuk \\ Candidate of Biological Sciences \\ Senior Lecturer \\ of Kharkiv National Medical University, \\ Kharkiv, Ukraine \\ https://orcid.org/0000-0003-1863-0265
}

\section{Natalya Kizilova}

Doctor of Physics and Mathematics

Professor of Department

of V.N. Karazin Kharkiv National University,

Kharkiv, Ukraine

https://orcid.org/0000-0001-9981-7616 


\title{
СИСТЕМА МОНІТОРИНГУ БІОФІЗИЧНИХ ВЛАСТИВОСТЕЙ ЕРИТРОЦИТІВ КРОВІ ПАЦІЄНТІВ ДЛЯ ЦІЛЕЙ МЕДИЧНОї ДІАГНОСТИКИ
}

\author{
Л.В. Батюк, Н.М. Кізілова
}

Сучасна медична діагностика неможлива без високотехнологічних засобів збору інформаиії о стані пацієнта, зокрема, біохімічних властивостей крові та інших тканин, фізіологічних сигналів у форматі часових рядів, а також медичних зображень. Широке використання автоматичних методів обробки інформації та прийняття рімень на основі математичних моделей, експертних систем, штучного інтелекту та ін. є невід'ємною складовою сучасної медицини. Такі підходи значно підвищують точність діагностики та ефективність призначеного лікування, але для цього потрібна наявність відповідно структурованих баз даних з попередніми результатами як успішного / неуспішного лікування, так $і$ повним набором потрібних аналізів та тестів для кожного пацієнта. $B$ даній роботі обговорюються найбільш важливі складові бази даних та системи моніторингу стану здоров'я населення. Головними є питання стандартизації формату даних, підходів, методів та використаного лабораторного обладнання для уніфікаціі моніторингу, діагностики та контролю за лікуванням. Показана важливість використання додаткових фізичних параметрів клітин крові та тканин для підвищення ефективності медичної діагностики за допомогою шттуного інтелекту. Наведені седиментаційні криві, які відповідають стабільній нормальній, підвищеній та нестабільній швидкості агрегаиії еритроцитів. Показано, що час досягнення максимальної швидкості осідання клітин може бути обчислений в рамках 2-фазної моделі крові, показники якої будуть накопичуватися в базі даних, що дасть можливість вилучення додаткової діагностичної інформачії за допомогою нових статистичних методів та математичних моделей. Наведені типові залежності діелектричної проникності еритроцитів від температури для онкологічних хворих. Показано, що зберігання в базі даних залежностей діелектричної проникності клітин та тканин від температури, які були виміряні на різних частотах, надає значний матеріал для більш детального вивчення закономірностей розвинення різних хвороб та пошуку найбільш чутливих показників для їх своєчасного виявлення.

Ключові слова: системи моніторингу, бази даних, прийняття рімень, біофізика, еритрочити, математичне моделювання, медична діагностика.

\section{СИСТЕМА МОНИТОРИНГА БИОФИЗИЧЕСКИХ СВОЙСТВ ЭРИТРОЦИТОВ КРОВИ ПАЦИЕНТОВ ДЛЯ ЦЕЛЕЙ МЕДИЦИНСКОЙ ДИАГНОСТИКИ}

\section{Л.В. Батюк, Н.Н. Кизилова}

Современная медииинская диагностика невозможна без высокотехнологичных средств сбора информаџии о состоянии паииента, в частности, биохимических свойств крови и других тканей, физиологических сигналов в формате временных рядов, а также медицинских изображений. Широкое использование автоматических методов обработки информации и принятия решения на основе математических моделей, экспертных систем, искусственного интеллекта и др. является неотъемлемой составляющей современной медицины. Такие подходы значительно повышают точность диагностики и эффективность назначенного лечения, но для этого требуется наличие соответственно структурированных баз данных предшествующих результатов как успешного / неуспешного лечения, так и полного набора нужных анализов и тестов для каждого пачиента. В данной работе обсуждаются наиболее важные составляющие базы данных и системы мониторинга состояния здоровья населения. Главными являются вопросы стандартизации формата данных, подходов, методов и использованного лабораторного оборудования для унификации мониторинга, диагностики и контроля за лечением. Показана важность использования дополнительных физических параметров клеток крови и тканей для повышения эффективности медицинской диагностики с помощью искусственного интеллекта. Приведены седиментационные кривые, соответствующие стабильной нормальной, повышенной и нестабильной скорости агрегаиии эритроциитов. Показано, что важный диагностический параметр - время достижения максимальной скорости оседания клеток, может быть вычислен в рамках 2-фазной модели крови, показатели которой будут накапливаться 6 базе данных, что даст возможность получения дополнительной диагностической информачии с помощью новых статистических методов и математических моделей. Приведены типичные зависимости диэлектрической проницаемости эритрочитов от температуры для онкологических больных в сравнении с кривыми для здоровых испытуемых. Показано, что хранение в базе данных зависимостей диэлектрической пронииаемости клеток и тканей от температуры, измеренных на разных частотах, предоставляет богатый материал для более детального изучения закономерностей развития различных заболеваний и поиска наиболее чувствительных показателей для их своевременного обнаружения.

Ключевые слова: системы мониторинга, базы данных, принятие решений, биофизика, эритрочиты, математическое моделирование, медииинская диагностика. 